\title{
PENINGKATAN KETERAMPILAN BERBICARA MELALUI METODE BERMAIN PERAN DI SEKOLAH DASAR
}

\author{
Hayani \\ Institut Agama Islam Negeri Palopo \\ Jl. Agatis I, Balandai, Bara, Kota Palopo, Sulawesi Selatan 91914 \\ E-mail: hayani14@email.com
}

\begin{abstract}
The main problem in this study is the low speaking skills of students in fifth grade at SDN 50 Bulu 'Datu in Palopo. The purpose of this study was to determine the results of the process of implementing speaking skills through the role playing method for fifth grade students of SDN 50 Bulu 'Datu in Palopo. This research is a classroom action research (CAR) which consists of two cycles, each cycle carried out as many as 3 meetings, with stages of planning, implementation, observation and reflection. Data collection techniques are carried out using observation, tests, documentation. The results of this study indicate that: by applying the use of role playing methods each cycle has increased. Based on the speaking skills of fifth grade students of SDN 50 Bulu 'Datu in Palopo, two cycles showed that students' speaking skills could increase, from the first cycle the average value was 71.10 with completeness $74.07 \%$, while the second cycle had an average score 76.72 with completeness of $92.59 \%$ and has met the KKM value of 70. Thus, the results of this study can be concluded that, by using the role playing method can improve the speaking skills of students in fifth grade SDN 50 Bulu 'Datu Pal opo city.
\end{abstract}

Keywords: Speaking Skills, Role Playing Methods.

\begin{abstract}
Abstrak
Pokok permasalahan dalam penelitian ini adalah rendahnya keterampilan berbicara siswa pada kelas V SDN 50 Bulu' Datu kota Palopo. Tujuan penelitian ini untuk mengetahui hasil proses pelaksanaan keterampilan berbicara melalui metode bermain peran pada siswa kelas $V$ SDN 50 Bulu' Datu kota Palopo. Penelitian ini merupakan penelitian tindakan kelas (PTK) yang terdiri dari dua siklus, masing-masing siklus dilaksanakan sebanyak 3 kali pertemuan, dengan tahapan perencanaan, pelaksanaan, observasi dan refleksi. Teknik pengumpulan data dilakukan dengan menggunakan observasi, tes, dokumentasi. Hasil penelitian ini menunjuk kan bahwa: dengan diterapkan penggunaan metode bermain peran setiap siklusnya mengalami peningkatan. Berdasarkan keterampilan berbicara siswa kelas V SDN 50 Bulu' Datu kota Palopo yang dilakukan sebanyak dua siklus menunjukkan bahwa keterampilan berbicara siswa dapat meningkat, dari siklus I nilai rata-ratanya 71,10 dengan ketuntasan 74,07\%, sedangkan siklus II nilai rata-ratanya 76,72 dengan ketuntasan 92,59\% dan sudah memenuhi nilai KKM yaitu 70. Dengan demikian, hasil penelitian ini dapat disimpulkan bahwa, dengan menggunakan metode bermain peran dapat meningkatkan keterampilan berbicara siswa pada kelas V SDN 50 Bulu'Datu kota Palopo.
\end{abstract}

Kata Kunci,: Keterampilan Berbicara, Metode Bermain Peran. 


\section{PENDAHULUAN}

Pendidikan harus mampu membuat siswa kreatif dan inovatif dalam membentuk pola pikir siswa di dalam pembelajaran. Hal ini sesuai dengan kajian teori yang dikemukakan oleh (Sukirman \& Rustan, 2010) yaitu "dalam konteks pendidikan multikultural yang berkarakter, pengajar harus mampu memberikan contoh-contoh pengaplikasian nilai dan tingkah laku kesehariannya. Kegiatan pendidikan siswa menjadi unsur yang penting dalam proses pembelajaran (Fuad Ihsan, 2015 : 1). Pendidikan dapat disalurkan dengan berbagai cara yang salah satunya adalah dengan berbicara. Berbicara termasuk dalam komunikasi langsung (tatap muka) (Anwar Arifin, 2008: 30). Keterampilan berbicara adalah menunjang keterampilan bahasa lainnya. Pembicara yang baik mampu memberikan contoh agar dapat ditiru oleh penyimak yang baik. Pembicara yang baik mampu memudahkan penyimak untuk menangkap pembicaraan yang disampaikan. Seseorang yang memiliki kemampuan berbicara akan lebih mudah dalam menyampaikan ide atau gagasan kepada orang lain, keberhasilan menggunakan ide itu sehingga dapat diterima oleh orang yang mendengarkan atau yang diajak berbicara (Rustan \& Hasriani, 2019). Sebaliknya, seseorang yang kurang memiliki kemampuan berbicara akan mengalami kesulitan dalam menyampaikan ide atau gagasan kepada orang lain.

Masalah dalam penelitian ini adalah kurangnya keterampilan berbicara siswa kelas V SDN 50 Bulu' Datu Kota Palopo dengan penggunaan metode pembelajaran yang menoton dari guru, yaitu metode ceramah. Metode ini hanya menekankan keaktifan guru, sedangkan siswa hanya mendengar dan mencatat apa yang diterangkan guru. Metode adalah suatu cara yang dipilih dan digunakan seorang guru untuk menyajikan dan melaksanakan proses belajar mengajar. Untuk pembelajaran bahasa Indonesia, khususnya keterampilan berbicara, metode yang cocok yaitu metode bermain peran, tanyajawab, demonstrasi, diskusi (Ayu Gustia Ningsih dkk, 2013: 3)

Berdasarkan masalah yang telah dijelaskan tersebut maka diupayakan mencari solusi untuk mengatasi masalah yang dihadapi siswa agar lebih terampil dan aktif dalam berbicara. Dengan demikian, metode bermain peran membuat keterampilan berbicara siswa menjadi lebih baik dan aspek keterampilan berbahasa lainnya pun dapat meningkat ( Zuniar Kamaluddin Mabruri dan Ferry Aristya, 2017 ). Berbicara merupakan alat untuk berkomunikasi yang alami antara anggota masyarakat untuk mengungkapkan pikiran dan sebagai bentuk tingkah laku social (Zainuddin,

PiJIES: Pedagogik Journal of Islamic Elementary School 
2018). Karena manusia akan merasa tidak nyaman atau merasa tersiksa tanpa adanya komunikasi. Kemampuan berkomunikasi ini membuat manusia berbeda dari mahluk lainnya yang ada di bumi, manusia berkomunikasi karena manusia tidak bisa hidup sendiri dan manusia berkomunikasi dengan orang lain untuk menyampaikan pikiran, gagasan atau perasaanya ( Yusal Iriantara, 2013: 5 ).

Keterampilan berbicara adalah kemampuan mengungkapkan pendapat atau pikiran dan perasaan kepada seseorang atau kelompok secara lisan, baik secara berhadapan langsung atuapun dengan jarak jauh. Keterampilan berbicara mendasari siswa untuk aktif dalam mengukuti proses belajar mengajar di kelas (Mariani Wulan Putri dkk, 2016:88)

Keterampilan berbicara yang masih rendah disebabkan faktor internal dalam diri siswa yaitu: (1) Siswa kurang aktif dalam pembelajaran berbicara karena metode yang digunakan oleh guru kurang inovatif; (2) Evaluasi untuk pembelajaran berbicara jarang dilakukan sehingga siswa tidak terbiasa untuk berlatih berbicara dan menganggap kegiatan berbicara mudah; (3) Dalam berbicara di depan kelas siswa kurang mampu mengorganisasikan perkataannya sehingga pembicaraan tidak terstruktur; (4) Dalam kegiatan berbicara siswa merasa, gugup, malu, dan kurang rileks, kondisi ini akan megurangi kualitas tuturan mereka; (5) Siswa kurang bisa merangkaikan ide dan gagasannya secara lengkap, mereka sering lupa dan tidak fokus dengan apa yang akan mereka sampaikan saat berada di depan kelas. Penyebab dari kesulitan berbicara tersebut tidak terlepas dari penggunaan metode pembelajaran yang digunakan oleh guru (Islawati, 2018).

Metode yang digunakan untuk meningkatkan keterampilan berbicara yaitu metode bermain peran. Metode bermain peran ialah permainan yang memerankan tokoh-tokoh atau benda sekitar anak sehingga dapat mengembangkan daya khayal ( imajinasi) dan penghayatan terhadap bahan kegiatan yang dilaksanakan ( Vera Ayuningtiyas, 2013 ). Tujuan metode bermain peran yaitu: ( a) Agar siswa dapat menghayati dan menghargai perasaan orang lain; b) Dapat belajar bagaimana membagi tanggung jawab; (c) Dapat belajar bagaimana mengambil keputusan dalam situasi kelompok secara spontan; (d) Merangsang kelas untuk berpikir dan memecahkan masalah ( Syaiful Bahri, 2010: 88 ). Jenis-jenis bermain peran yaitu: (1) Metode bermain peran makro adalah bermain yang sifatnya kerja sama lebih dari 2 orang bahkan lebih khususnya untuk anak usia taman kanak-kanak; (2) Metode bermain peran mikro adalah awal bermain kerja sama dilakukan hanya 2 orang saja bahkan sendiri (Nur Azizah, 2013). 


\section{4 | Hayani}

Kelebihan metode bermain peran yaitu: (1) Siswa melatih dirinya untuk memahami, dan mengingat isi bahan yang akan didramakan. Sebagai pemain harus memahami, menghayati isi cerita secara keseluruhan, terumata untuk materi yang harus diperankannya. Dengan demikian, daya ingatan siswa harus tajam dan tahan lama; (2) Siswa akan terlatih untuk berinisiatif dan berkreatif. Pada waktu main drama para pemain dituntut untuk mengemukakan pendapatnya sesuai dengan waktu yang tersedia; (3) Bakat yang terdapat pada siswa dapat dipupuk sehingga dimungkinkan akan muncul atau tumbuh bibit seni drama dari sekolah. Jika seni drama mereka dibina dengan baik kemungkinan besar mereka akan menjadi pemain yang baik kelak; (4) Kerja sama antar pemain dapat ditumbuhkan dan dibina dengan sebaik baiknya; (5) Siswa memperoleh kebiasaan untuk menerima dan membagi tanggung jawab dengan sesamanya; (6) Bahasa lisan siswa dapat dibina menjadi bahasa yang baik agar mudah dipahami orang lain.

Kelemahan metode bermain peran yaitu: (1) Sebagian besar anakyang tidak ikut bermain drama mereka menjadi kurang kreatif; (2) Banyak memakan waktu, baik waktu persiapan dalam rangka pemahaman isi bahan pelajaran maupun pada pelaksanaan pertunjukan; (3) Memerlukan tempat yang cukup luas, jika tempat bermain sempit menjadi kurang bebas; (4) Sering kelas lain terganggu oleh suara pemain dan para penonton yang kadang-kadang bertepuk tangan dan sebagainya ( Syaiful Bahri Djamarah dan Aswan Zain, 2010: 89-90 ). Dalam penelitian ini penulis menggunakan metode bermain peran untuk meningkatkan keterampilan berbicara siswa, oleh karena itu penelitian ini bertujuan: (1) Mengetahui penerapan metode bermain peran pada siswa kelas V SDN 50 Bulu' Datu kota Palopo; (2) Mengetahui metode bermain peran dalam meningkatkan keterampilan menulis karangan narasi pada siswa kelas IV A SDN 50 Bulu' Datu kota Palopo.

\section{Metode Penelitian}

Jenis penelitian yang digunakan dalam penelitian ini yaitu penelitian tindakan kelas ( PTK ). Pendekatan yang digunakan adalah pendekatan kuantitatif dan kualitatif. Penelitian ini berlokasi di Jl. Kakatua kompleks perumnas kelurahan Rampoang Kota Palopo. Kemudian penelitian ini dilaksanakan di kelas V SDN 50 Bulu' Datu kota Palopo mata pelajaran bahasa Indonesia tahun ajaran 2018/2019 semester ganjil dengan jumlah 27 siswa yang terdiri dari 12 orang laki-laki dan 15 orang perempuan. Untuk mengumpulkan data dalam penelitian ini dilakukan dengan observasi, recording, dan dokumentasi. Sesuai dengan jenis penelitian yang dipilih, maka penelitian ini menggunakan model penelitian tindakan dari Kurt Lewin, PiJIES: Pedagogik Journal of Islamic Elementary School 
penulis menggunakan model Kurt Lewin karena model Kurt Lewin merupakan model yang penulis anggap mudah yaitu ia menjelaskan bahwa ada hal harus dilakukan dalam proses penelitin tindakan yakni perencanaan, tindakan, observasi, dan refleksi.

\section{HASIL PENELITIAN}

1. Penerapan metode bermain peran pada siswa kelas V SDN 50 Bulu' Datu Kota Palopo.

Perencanan: pada tahap ini hal-hal yang dilakukan tahap perencanaan ini sebagai berikut: Penulis dan guru menetapkan waktu pelaksanaan penelitian tindakan kelas yang diadakan setiap hari kamis, jum'at dan sabtu dilaksanakan selama tiga kali pertemuan, penulis dan guru membuat skenario pembelajaran dan perangkat pembelajaran, yaitu Rencana Pelaksanaan Pembelajaran (RPP). Pelaksanaan tahap ini, kegiatan pembelajaran dilaksanakan sesuai dengan rencana pelaksanaan pembelajran (RPP) yang telah dipersiapkan sebelumnya. pelaksanaannya: Pada pertemuan pertama, kedua dan ketiga siklus I, penulis membuka pelajaran dengan mengucapkan salam, berdoa sebelum pelajaran dimulai dan mengapsen siswa, penulis bertanya kepada siswa menegenai cara bermain drama setelah itu guru membagi siswa menjadi beberapa kelompok kemudian guru membagikan naskah drama pada setiap kelompok untuk diperankan, setelah selesai guru membagikan naskah drama pada setiap kelompok maka diberikan kesempatan beberapa menit, kemudian guru akan menunjuk salah satu kelompok untuk bermain drama di depan kelas dan begitu seterusnya sampai semua kelompok maju ke depan. Sementara, guru memberikan nilai kepada masing- masing siswa. Obsevasi yang dilakukan penulis untuk mengetahui proses pembelajaran yang dilakukan dan aktivitas siswa dalam kegiatan pembelajaran dengan mengunakan lembar observasi yang telah disiapkan oleh penulis dan yang menjadi sasaran obsevasi penulis yaitu aspek kognitif. Data hasil penelitian kognitif. (pengamatan) dilakukan untuk siswa, dan indikator aspek proses pembelajaran yang dilakukan guru dalam kegiatan pembelajaran yang dilakukan guru meliputi perencanaan, kegiatan utama, dan pemantapan. kegiatan utama, dan pemantapan, Refleksi : Tahap selanjutnya adalah mengadakan refleksi yaitu membahas dan mengevaluasi kegiatan pembelajaran yang baru saja dilaksanakan.

Tahap selanjutnya adalah mengadakan refleksi merupakan bagian yang penting dalam proses penelitian tindakan kelas. Refleksi merupakan kegiatan untuk melihat kembali apa yang telah dilakukan, dan mengkaji secara mendalam kelebihan dan kekurangan dari tindakan yang diterapkan pada pembelajaran di dalam kelas dan mempertimbangkan proses, masalah, 
persoalan, kendala, dan hasil yang diperoleh dari pengamatan. Pada tahap refleksi, penulis bersama guru melakukan evaluasi proses pembelajaran yang telah dilakukan. Hal ini dilakukan untuk mengetahui seberapa besar peningkatan keterampilan berbicara siswa dengan penerapan metode bermain peran. Hasil tes keterampilan berbicara siklus I mengalami peningkatan dibandingkan dengan hasil tes prasiklus, akan tetapi peningkatan tersebut belum pencapaian KKM.

Melihat hambatan tersebut maka perlu diadakan tindakan perbaikan agar hasil pembelajaran pada siklus II bisa lebih optimal. Kegiatan pembelajaran yang akan dilaksanakan pada siklus II penampilan mengajar guru akan ditingkatkan secara lebih baik dengan mengacu kepada kelemahan atau kendala-kendala yang terjadi pada siklus I.

2. Metode bermain Peran dalam meningkatkan keterampilan berbicara pada siswa kelas V SDN 50 Bulu' Datu kota Palopo.

Penggunaan metode bermain peran dala m proses pembelajaran yang dilakukan secara bertahap yaitu dua siklus mengalami suatu peningkatan yang cukup signifikan, keterampilan berbicara siswa pada siklus I yang masih berkategori 'Cukup' dengan nilai rata-rata 71,10 dengan ketuntasan belajar $74,07 \%$ meningkat pada siklus II dengan kategori 'Baik' dengan nilai ratarata 76,72 dan ketuntasan belajar 92,59\%. Dengan demikian penerapan metode bermain peran untuk peningkatan kerampilan berbicara siswa kelas V SDN 50 Bulu' Datu kota Palopo. Untuk lebih jelasnya gambaran tes siklus 1 keterampilan berbicara dengan menggunakan metode bermain peran pada siswa kelas V SDN 50 Bulu' Datu kota Palopo dapat dilihat pada diagram berikut:

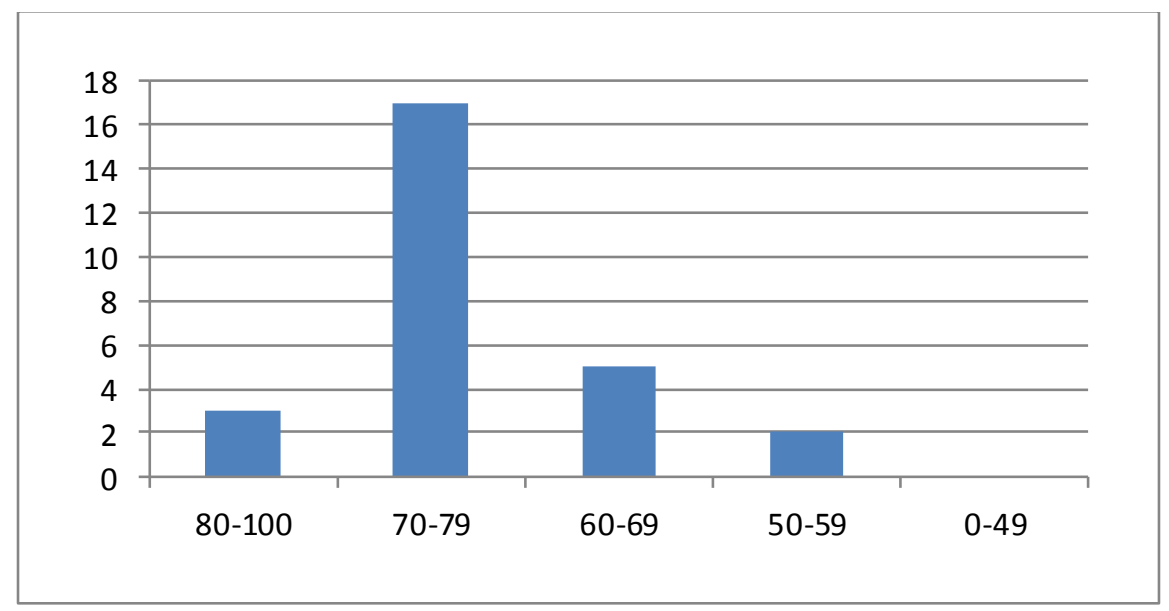

Gambar 1. Diagram hasil tes siklus I

PiJIES: Pedagogik Journal of Islamic Elementary School 
Berdasarkan penelitian tes pada tahap siklus I siswa kelas V SDN 50 Bulu' Datu kota Palopo sebagaimana pada diagram menunjukkan keterampilan berbicara siswa kelas V SDN 50 Bulu' Datu kota Palopo mengalami peningkatan. Namun, peningkatan tersebut belum mencapai nilai maksimal sehingga penulis perlu melanjutkan penelitian pada siklus II. Untuk lebih jelasnya gambaran tes siklus II siswa kelas V SDN 50 Bulu' Datu kota Palopo dapat dilihat pada diagram berikut:

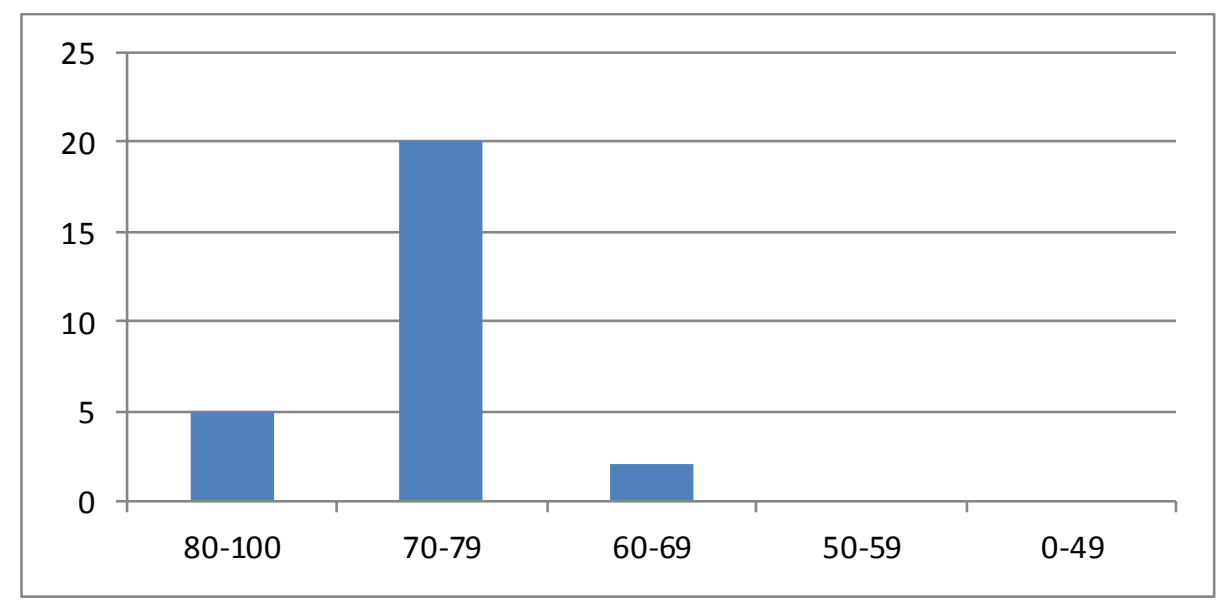

Gambar 1. Diagram hasil tes siklus I

Berdasarkan hasil tes evaluasi pada siklus II sebagaimana pada Diagram tersebut menunjukkan bahwa keterampilan berbicara dengan menigkatkan metode bermain peran pada siswa kelas V SDN 50 Bulu' Datu kota Palopo telah mencapai nilai rata-rata 76,72 dengan persentase ketuntasan 92,59\%. Berdasarkan nilai kriteria ketuntasan minimum mata pelajaran bahasa Indonesia dengan standar KKM 70. Sehingga penulis mengakhiri tindakan penelitian ini sampai pada siklus II. Berdasarkan hasil tes awal, siklus I dan siklus II tersebut menunjukkan bahwa terjadi peningkatan terhadap keterampilan berbicara siswa pada kelas V SDN 50 Bulu' Datu kota Palopo. Jadi, dengan menggunakan metode bermain dapat meningkatkan keterampilan berbicara siswa.

Adapun rekapitulasi hasil berbicara siswa pada tindakan kelas dapat dilihat pada tabel sebagai berikut:

Tabel 1. Rekapitulasi hasil berbicara siswa pada tindak kelas

\begin{tabular}{|l|l|l|l|}
\hline Uraian & Tes awal & Siklus I & Siklus II \\
\hline Rata-rata & 63,14 & 71,10 & 76,72 \\
\hline Ketuntasan belajar secara klasikal & $18,51 \%$ & $74,07 \%$ & $92,59 \%$ \\
\hline
\end{tabular}




\section{8 | Hayani}

Berdasarkan hasil deskriptif tabel tersebut menunjukkan bahwa secara rekapitulasi pada tes hasil belajar siswa selalu meningkat. Setelah dilakukan dua siklus, ditinjau secara klasikal peningkatannya adalah 18,51\% pada tes awal, kemudian meningkat menjadi $74,07 \%$ pada siklus I, dan pada siklus II meningkat menjadi 92,59\%. Ini berarti penggunaan metode bermain peran pada siswa kelas V SDN 50 Bulu' Datu Kota Palopo dapat meningkat.

\section{PEMBAHASAN PENELTIAN}

Penelitian ini merupakan penelitian tindakan kelas terdiri dari dua siklus. Setiap siklus terdari 3 kali pertemuan. Penelitian ini menerapkan metode yaitu metode bermain peran untuk meningkatkan keterampilan berbicara siswa pada pembelajaran bahasa Indonesia di kelas V SDN 50 Bulu' Datu kota Palopo.

Hasil penelitian yang telah dilakukan sebanyak dua siklus menunjukkan bahwa metode bermain peran mampu meningkatkan keterampilan berbicara siswa. Terlihat dari hasil tes evalusi siklus I dengan nilai rata-rata 71,10 dan kriteria ketuntasan belajarnya mencapai 74-07\%, mengalami peningkatan pada siklus II yakni nilai rata-rata 76,72 dengan kriteria ketuntasan belajarnya mencapai 92,59\%. Berikut perbandingan hasil pembelajaran tahap siklus I dan siklus II. Tujuan pembelajaran yang telah ditetapkan telah tercapai dengan baik, siswa juga sudah mampu main drama. Pemahaman siswa mengenai drama yang diajarkan telah meningkat.

Hal ini menunjukkan bahwa penerapan metode bermain peran merupakan salah satu metode yang sangat baik dalam meningkatkan keterampilan berbicara siswa terhadap mata pelajaran bahasa Indonesia. Selain itu, peningkatan juga terjadi karena adanya motivasi yang guru berikan kepada siswa, siswa merasa terangsang serta terdorong untuk melakukan kegiatan yang berhubungan dengan pembelajaran yang sedang berlangsung sehingga nilai rata-rata yang siswa dapatkan meningkat atau mengalami perubahan. Hal ini sejalan dengan pendapat David McClelland et al, yang dikutip oleh Hamzah B Uno yaitu motif merupakan implikasi dari hasil pertimbangan yang telah dipelajari (redintegration) dengan ditandai suatu perubahan pada situasi afektif. Sumber utama munculnya motif adalah dari rangsangan (stimulasi) perubahan situasi sekarang dengan situasi yang diharapkan (Hamsa B Uno: 2015: 9).

Sehingga tanda perubahan tersebut tampak pada adanya perbedaan afektif saat munculnya motif dan saat usaha pencapaian diharapkan. Selain pemberian motivasi guru juga memberika hadiah pada siswa yang mendapat nilai tertinggi pada akhir pembelajaran untuk membangkitkan semnagat

PiJIES: Pedagogik Journal of Islamic Elementary School 
belajar siswa. Seperti pendapat Mamiq Gaza (2012:88) teknik memberikan reward atau bonus belajar menyenagkan bagi siswa yang berhasil menunjukkan prilaku posif-positif tertentu. Pendapat lain yang sama yaitu B.F Skinner (Sudarwan Danim Khair, 2014:107) siswa akan mengulangi prilaku yag diinginkan jika prilaku yang positif. Penguatan positif atau "imbalan" dapat mencakup penguatan verbal seperti "bagus", "bagus sekali", "sukses selalu", "pertahankan prestasimu", dan sebagainya.

Hal ini menunjukkan bahwa penerapan metode bermain peran merupakan salah satu metode yang sangat baik diterapkan dalam meningkatkan keterampilan berbicara siswa terhadap mata pelajaran bahasa Indonesia. Terlihat dari perubahan atau peningkatan nilai rata-rata yang di capai oleh siswa yaitu dari prasiklus 63,14 dengan ketuntasan 18,51\%, siklu s I 71,10 dengan ketuntasan 74,07\%, dan siklus II 76,72 dengan ketuntasan 92,59\%. Berdasarkan data yang diperoleh dari prasiklus, siklus I dan siklus II dapat disimpulkan bahwa penerapan metode bermain peran untuk meningkatkan keterampilan berbicara siswa kelas V SDN 50 Bulu' Datu kota Palopo meningkat.

\section{PENUTUP}

Berdasarkan hasil dari analisis data penelitian, maka dapat di tarik kesimpulan sebagai berikut: (1) Metode bermain peran adalah permainan yang memerankan tokoh-tokoh atau benda sekitar anak sehingga dapat mengembangkan daya khayal ( imajinasi) dan penghayatan terhadap bahan kegiatan yang dilaksanakan, metode ini diterapkan pada siswa kelas V SDN 50 Bulu' Datu kota Palopo dengaan cara membagi kelompok menjadi 5, membagikan naskah dramah, setelah dibagikan naskah drama kemudian siswa diberikan kesempatan untuk latihan, kemudian setelah latihan siswa disuruh bermain drama sesuai kelompok yang ditunjuk; (2) Penggunaan metode bermain peran dalam proses pembelajaran yang dilakukan secara bertahap yaitu dua siklus mengalami suatu peningkatan yang cukup signifikan, keterampilan berbicara siswa pada siklus I yang masih berkategori 'Cukup' dengan nilai rata-rata 71,10 dengan ketuntasan belajar $74,07 \%$ meningkat pada siklus II dengan kategori 'Baik' dengan nilai ratarata 76,72 dan ketuntasan belajar 92,59\%. Dengan demikian penerapan pembelajaran metode bermain peran untuk peningkatan kerampilan berbicara siswa kelas V SDN 50 Bulu' Datu kota Palopo.

\section{DAFTAR PUSTAKA}

Arifin, Anwar. 2008. Ilmu Komunikasi Sebuah Pengantar Ringkas,: Jakarta: PT Raja Grafindo Persada. 
Ayuningtiyas,Vera "Metode Bermain Peran ( Role Playing) Dalam Upaya Menumbuhkan Keterampilan berbicara Bahasa Indonesia pada Anak Usia Dini Di TK Bhayangkari 17 Cimahi”,Jurnal, 2013.

Azizah, Nur dkk, "Tingkat Keterampilan Berbicara Ditinjau Dari Metode Bermain Peran Pada Anak 5-6 Tahun, 2013.

Djamarah, Bahri, Syaiful Dan Zain, Aswan. 2010. Strategi Belajar Mengajar, Jakarta: Rineka Cipta.

Gaza, Mamiq. 2012. Bijak Memghukum Siswa, Cet. I, Jokjakarta: Ar-ruzz Media.

Ihsan, Fuad, 2015. Dasar - Dasar Kependidikan Jakarta : Rineka Cipta.

Ningsih,Gustia,Ayu. Peningkatan Keterampilan Berbicara Melalui Metode Bermain Teka-Teki Siswa Kelas X MAS-TI Tabek Gadang Kabupaten Lima Puluh Kota, Jurnal, 2013.

Iriantara, Yusal dkk, 2013. Komunikasi Pendidikan, Cet.1: Bandung; PT Remaja Rosdakarya.

Islawati. (2018). Penerapan Model Picture And Picture untuk Meningkatkan Keaktifan Keterampilan Berbicara Dalam Mata Pelajaran Bahasa Indonesia Pada Siswa Kelas III MI Al-Mawasirpadang Kaluadul. Pedagogik Journal of Islamic Elementary School, 1(2), 151-160.

Khair, Denim, Sudarwan. 2011. Pengantar Pendidikan. Cet. II. Bandung: Alfabeta.

Mabruri, Kamaluddin, Zuniar dkk. "Peningkatan Keterampilan Berbicara Pembelajaran Bahasa Indonesia Kelas IV Melalui Penerapan Strategi Role Playing SD Negeri Ploso 1 Pacitan,"Jurnal, 2017.

Rustan, E., \& Hasriani. (2019). Application of Therapeutic Nurse Communication to Self Concept as Reviewed from the Anxiety Level of Tuberculosis Patients. International Journal of Caring Science, 12(2), 979-986.

Sukirman, N., \& Rustan, E. (2010). Kunci Sukses Belajar Bahasa Indonesia. Palopo: Lembaga Penerbitan STAIN (LPS) STAIN Palopo.

Uno, B Hamsa, 2015. Teori Motivasi \& Pengukurannya Analisis Di Bidang Pendidikan, Cet. 12 Jakarta, PT Bumi Aksara.

Putri,Wulan,Mariani, Peningkatan Keterampilan Berbicara Dengan Menggunakan Metode Talking Stick Pada Siswa Kelas VIII SMP Negeri 4 Denpasar Tahun Ajaran 2015/2016, Jurnal, 2016.

Zainuddin, N. (2018). Upaya Meningkatkan Keterampilan Berbicara Bahasa Indonesia Melalui Penerapan Metode Debat Pada Siswa Kelas V SD N 09 Matekko Kecamatan Bara Kota Palopo. Pedagogik Journal of Islamic Elementary School, 1(2), 139-150.

PiJIES: Pedagogik Journal of Islamic Elementary School 